\title{
Taxonomic Reports of Otobothrioidea (Eucestoda, Trypanorhyncha) from Elasmobranch Fishes of the Southern Coast Off Brazil
}

\author{
Marcelo Knoff/+ , Sérgio Carmona de São Clemente*, Roberto Magalhães Pinto, \\ Reinalda Marisa Lanfredi**, Delir Corrêa Gomes
}

\begin{abstract}
Laboratório de Helmintos Parasitos de Vertebrados, Departamento de Helmintologia, Instituto Oswaldo Cruz-Fiocruz, Av. Brasill 4365, 21045-900 Rio de Janeiro, RJ, Brasil *Laboratório de Inspeção e Tecnologia de Alimentos, Faculdade de Veterinária, Universidade Federal Fluminense, Niterói, RJ, Brasil **2aboratório de Biologia de Helmintos Otto Wucherer, Instituto de Biofísica Carlos Chagas Filho, Universidade Federal do Rio de Janeiro, Rio de Janeiro, RJ, Brasil
\end{abstract}

Specimens of elasmobranch fishes, captured in the states of Paraná and Santa Catarina, of the southern coast off Brazil, represented by three families, four genera, and four species, were parasitized with otobothrioid trypanorhynch cestodes: Heptranchias perlo (Bonnaterre, 1788), Squalus sp. and Carcharhinus signatus (Poey, 1868) were parasitized with Progrillotia dollfusi Carvajal \& Rego,1987; Prionace glauca (Linnaeus, 1758) with Molicola horridus (Goodsir, 1841) Dollfus, 1942. Details of internal morphology and/or scolex and/or proglottids surface ultrastructure, that expanded the description of M. horridus, through observations with lightfield, and/or scanning eletronic microscopy, are provided. The known geographical distribution for the species M. horridus is enlarged. P. dollfusi is reported for the first time in elasmobranchs.

Key words: Trypanorhyncha/Otobothrioidea - taxonomic reports - elasmobranchs - Brazil

This investigation reports a taxonomic study of otobothrioid trypanorhynch cestodes parasitizing elasmobranchs, with discussion of the species, based on metacestodes (plerocerci) and adults, collected during two trips to the coast of the states of Paraná and Santa Catarina, South of Brazil.

During the three last decades in Brazil, most reports of specimens of this superfamily have been in teleost fishes (Carvajal \& Rego 1983, São Clemente 1986a,b, 1987, Rego 1987, São Clemente et al. 1991, 1993, 1995, 1997, Pereira Jr 1993, 1998, Palm 1997, Alves \& Luque 1999, 2000, 2001a,b) with only one report from elasmobranchs (Rego et al. 1974).

Progrillotia dollfusi Carvajal \& Rego, 1987 was found parasitizing Heptranchias perlo (Bonnaterre, 1788), Squalus sp. and Carcharhinus signatus (Poey, 1868) off the coast of states of Paraná and Santa Catarina. It was described from Cynoscion striatus (Cuvier, 1829) in the state of Rio de Janeiro and also was reported in other sciaenids from the state of Rio Grande do Sul (Rego 1987, Pereira Jr 1998).

Molicola horridus (Goodsir, 1841) Dollfus, 1935, collected from the spiral valve of Prionace glauca (Linnaeus, 1758) from the state of Santa Catarina, had already been reported from teleosts, mainly in the liver and muscles of Mola mola (Linnaeus, 1758), in France, the Mediterra-

Partial financial support: $\mathrm{CNPq}$ and Faperj

${ }^{+}$Corresponding author. Fax: +55-21-2598.4362. E-mail: knoffm@ioc.fiocruz.br

Received 19 August 2003

Accepted 26 December 2003 nean region, Canada, Japan, New Zealand, and India and also from the musculature of Thyrsites sp. from Holland (Dollfus 1942, Bates 1990). In elasmobranchs, this species was reported from the spiral valve of Isurus oxyrinchus Rafinesque, 1810 in Japan and south California, US (Iwata 1939, Heinz \& Dailey 1974).

\section{MATERIALS AND METHODS}

In March 1998, 30 elasmobranchs, 7 specimens ( 6 females and 1 male) of Heptranchias perlo, $87-107.4 \mathrm{~cm}$ in total length (tl), 16 specimens (10 females and 6 males) of Squalus sp., 41-67 cm (tl) and 7 specimens (1 female and 6 males) of Carcharhinus signatus, $120-150 \mathrm{~cm}(\mathrm{tl})$ were captured about 125 miles off the coast of the state of Paraná (25 $50^{\prime}$ 'S $-25^{\circ} 52^{\prime} \mathrm{S}, 45^{\circ} 23^{\prime} \mathrm{W}-45^{\circ} 25^{\prime} \mathrm{W}$; $200-500 \mathrm{~m}$ in depth), by professional fishermen of the Icanhema VI fish boat, and in March 1999, more 30 elasmobranchs, 18 females, and 12 males, of Prionace glauca, 206-287 cm (tl), were captured about 190 miles off the coast of the state of Santa Catarina (27 $08^{\circ}$ 'S-28 $38^{\circ} \mathrm{S}, 45^{\circ} 30^{\prime} \mathrm{W}-46^{\circ} 53^{\prime} \mathrm{W}$; 25-50 m) by professional fishermen of the Kiyomã tuna fish boat. On board, stomachs and spiral valves, were collected, labelled and cooled on ice prior to examination. Cestodes were recovered, fixed, stained and mounted according to the technique of Amato et al. (1991). Taxonomic classification is in accordance with Campbell and Beveridge (1994). Measurements and terminology follow Dollfus (1942) and Campbell and Beveridge (1994). Measurements are in millimeters $(\mathrm{mm})$ unless otherwise indicated. In the taxonomic summaries, the total number of parasitized specimens and the infrapopulation of each host are indicated. NH refers to new host and NGD to new geographical distribution; drawings were made with the aid of a drawing tube connected to a lightfield Olympus BH-2 microscope (LM). One specimen of $M$. horridus was observed under 
a variable pressure scanning electron microscope (VPSEM) - LEO 435; following this procedure, the same sample was routinely prepared and examined under a scanning electron microscope (SEM) - JEOL. Representative specimens were deposited in the Coleção Helmintológica do Instituto Oswaldo Cruz (CHIOC), Rio de Janeiro, Brazil; samples for comparison were also obtained from the CHIOC and from the Múseum National d'Histoire Naturelle, Paris (MNHN). At least one host specimen of each investigated fish species was deposited as symbiotypes sensu Brooks (1993) in the collection of the Instituto de Pesca, Santos, SP, Brazil and listed by Knoff et al. (2001a,b).

\section{RESULTS \\ Otobothrioidea Dollfus, 1942 \\ Grillotiidae Pintner,1969 \\ Progrillotia Dollfus, 1946 \\ Progrillotia dollfusi Carvajal \& Rego, 1983}

Hosts/site of infection: four specimens from the stomach of one male of Carcharhinus signatus (NH), one specimen from the spiral valve of one female of Heptranchias perlo $(\mathrm{NH})$ and one specimen from the spiral valve of one female of Squalus sp. (NH).

Locality: coast of the state of Paraná.

Specimens deposited: CHIOC $34505 \mathrm{a}-\mathrm{b}$ and 34506-7.

Material examined: P. dollfusi. Plerocerci from Cynoscion striatus (Cuvier, 1829), Rio de Janeiro, Brazil [CHIOC 32018 a (type) - d] and from C. guatucupa (Cuvier, 1830), $C$. jamaicensis (Vaillant \& Bocourt, 1883), Macrodon ancylodon (Bloch \& Schneider, 1801), Ctenosciaena gracilicirrhus (Metzelaar, 1919), Umbrina canosai Berg, 1895, Menticirrhus americanus (Linnaeus, 1758), M. littoralis (Holbrook, 1855), Paralonchurus brasiliensis (Steindachner, 1875), Micropogonias furnieri (Desmarest, 1823), Rio Grande do Sul, Brazil (CHIOC 33725-33735). Trypanorhyncha sp. ( = P. dollfusi). Plerocerci from $C$. striatus, Rio de Janeiro, Brazil (CHIOC 29116 and 31044 (alcohol).

Remarks: the six metacestodes studied agreed with the description of P. dollfusi (Carvajal \& Rego 1983) and the redescription of Pereira Jr (1998), when this species was reported parasitizing sciaenid hosts in the littoral of the states of Rio de Janeiro and Rio Grande do Sul, respectively.

The presence of this cestode species in C. signatus, H. perlo, and Squalus sp. represents new host records and the first reference in elasmobranchs.

\section{Molicolidae Beveridge \& Campbell, 1989 Molicola Dollfus, 1935 \\ Molicola horridus (Goodsir,1841) Dollfus, 1942}

(Figs 1-12)

Description based on two adults, one whole mounted and measured and one oberved under VPSEM and SEM. Scolex elongate, cylindrical, acraspedote, 4.38 long, 0.70 wide. Maximum width 0.70 either at the bothridial portion or at the pars bulbosa. Pars bothridialis with four auriculate elongate bothridia, curved and inclined apically, rims thickened, with rounded edges, in two separate pairs on opposite faces of the scolex, each pair united by velum, posterior and lateral edges free, merged with scolex anteriorly, with their concave faces side by side, 1.4 long by 0.70 wide. Pars vaginalis 2.88 long. Pars bulbosa 1.11 long, 0.44 wide, retractor muscles originating in the anterior half of bulb. Bulbs longer than wider, 1.04 long, 0.22-0.24 wide. Prebulbar organs absent. Pars postbulbosa 0.70 long. Tentacular orifices on the anterior surface of the bothridial rims. Tentacles partially extroverted up to 3.70 including a proximal unarmed region. Proximal region cylindrical, with a plicate appearance, unarmed, $0.60-1.10$ long, 0.12 wide. Distinctive basal armature $0.16-0.18$ wide, with a corona of long falciform hooks with rounded extremities. The corona of the long falciform hooks around the base of the tentacles has a pattern of distribution in a glide reflection symmetry consisting in half-spiral rows of hooks, ascending from the internal to the external face. Hooks of the corona are hollow (LM) and porous (SEM). Tentacles one and two have one great central hook (1C) and six hooks in each half-spiral row: 2(2'), 3(3'), 4(4'), 5(5'), 6(6') and $7\left(7^{\prime}\right)$. Tentacles three and four, have 7 hooks in each

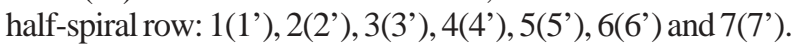
The hooks 1C / 1(1'), 2(2'), 3(3'), 4 (4'), are large and the hook 2(2') is the largest; 5(5') is median; 6(6') and 7(7') are the smallest. The hooks 1C (central, on the tentacles 1 and 2) and $1\left(1^{\prime}\right)$ (on the tentacles three and four) $0.100 \mathrm{x}$ 0.032 to $0.120 \times 0.040$ (length $\mathrm{x}$ base), 2 (2') $0.140 \times 0.048$ to $0.160 \times 0.056,3\left(3^{\prime}\right) 0.088 \times 0.036$ to $0.108 \times 0.040,4\left(4^{\prime}\right) 0.108$ $\mathrm{x} 0.040$ to $0.128 \times 0.052,5\left(5^{\prime}\right) 0.068 \times 0.020$ to $0.084 \times 0.028$, $6\left(6^{\prime}\right) 0.020 \times 0.004$ to $0.028 \times 0.006,7\left(7^{\prime}\right) 0.016 \times 0.002$ to $0.020 \times 0.004$. Metabasal armature heteromorphous, hooks hollow, consisting in half-spiral rows of hooks, ascending, from the internal to the external face, longest hooks at the middle of the row, with 10 hooks each, separated by a band of small hooks on the middle of the external face. Hooks 1(1') robust, unciform, with wide bases, internal face, $0.024-0.080$ by $0.012-0.064$ (length $\mathrm{x}$ base), hooks $2\left(2^{\prime}\right.$ ) with narrower bases, $0.028-0.084 \times 0.016-0.048$, hooks $3\left(3^{\prime}\right)$, falciform, $0.032-0.0921 \times 0.024-0.032$, hooks 4(4') 0.028$0.100 \times 0.016-0.040$, hooks $5\left(5^{\prime}\right)$ 0,032-0,100 x 0,016-0,028, hooks 6(6') $0.036-0.088 \times 0.012-0.028$. From this region distally, the hooks become straighter, spiniform, diminishing in length; hooks 7(7') are 0.032-0.068 x 0.012-0.024, hooks $8\left(8^{\prime}\right) 0.032-0.056$ x 0.008-0.016, hooks $9\left(9^{\prime}\right) 0.028-0.040$ x $0.008-0.016$, hooks $10\left(10^{\prime}\right) 0.028-0.032 \times 0.008-0.012$. There is a band of small spiniform hooks in the middle of the external face, disposed obliquely, in sets of three rows of four elements each, one behind the other, with an inclination of about $45^{\circ}$, opposite, alternate, forming continuous longitudinal bands from the basal portion of the tentacle to the tip. Initially, these hooks are smaller and gradativelly increase in length towards the tip and are 0.018-0.020 long and 0.004-0.006 wide. The first elements of the band of small hooks, alined to the 1 st and the 2 nd principal rows of hooks, almost merging with the principal rows, are 0.012-0.040 x 0.004-0.012. Strobila, hyperapolytic, about 6 $\mathrm{cm}$ long. Proglottids acraspedote, initially wider than longer. Genital pores, pre-equatorial, marginal and irregularly alternate, surrounded by papillae. Mature proglottids wider than longer, 1.48-1.84 long, 2.74-2.90 wide. Gravid proglottids 1.24-2.56 long, 2.50-3.14 wide. Internal struc- 
tures inconspicuous. By SEM, papillae around the genital pore were observed. Eggs not collapsed 0.040-0.056 long, 0.028-0.036 wide.

Host/site of infection: two specimens from spiral valve of one female of Prionace glauca (NH; NGD).
Locality: coast of the state of Santa Catarina. Specimens deposited: CHIOC 34508 a-b.

Material examined: plerocerci. From Orthagoriscus mola (Linnaeus, 1758) (= Mola mola), Concarneau, France (MNHN bocal C85).
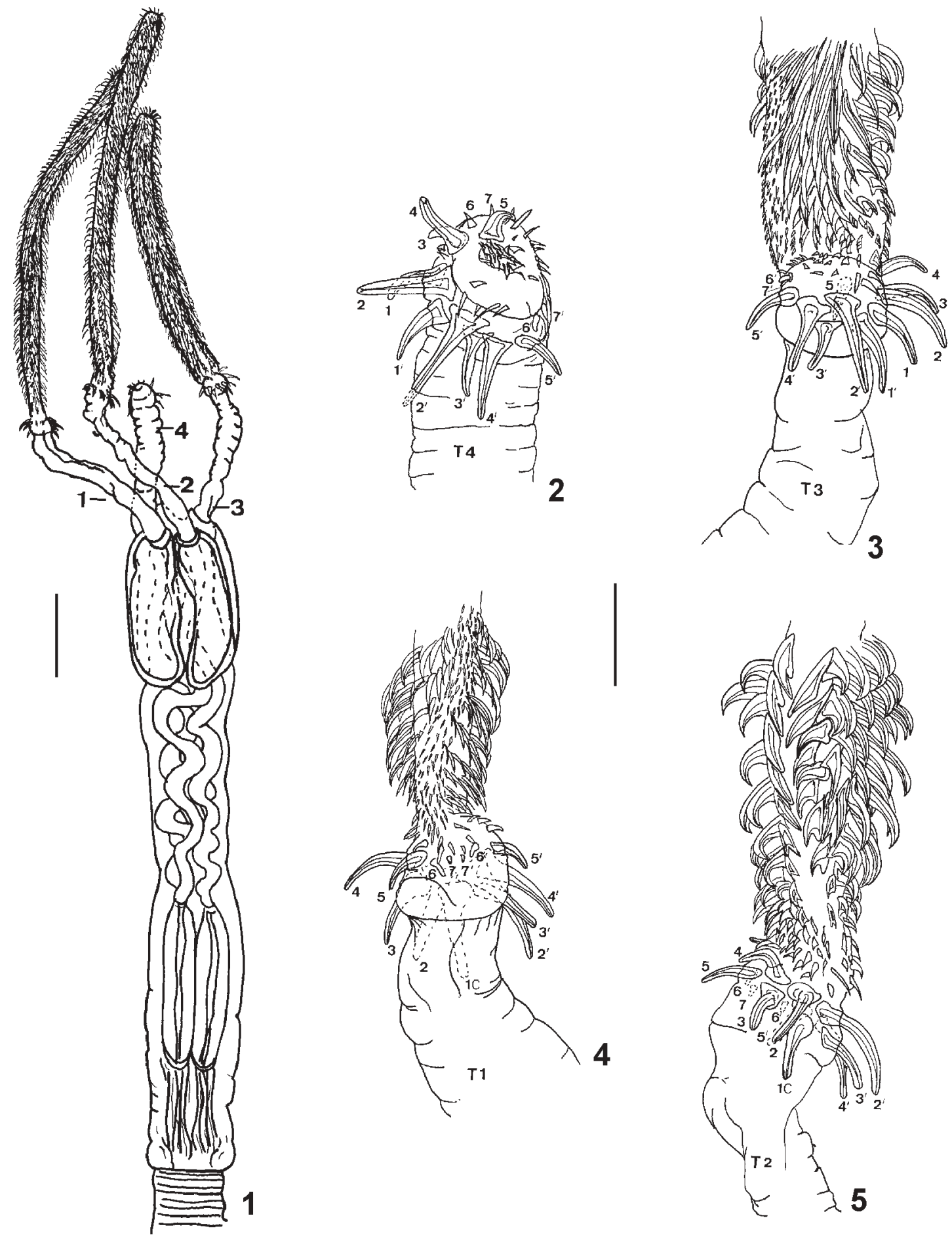

Molicola horridus. Fig. 1: scolex. Fig. 2: tentacle 4, basal, corona of long hooks, with hooks 1 and 1', internal face on the left. Fig. 3: tentacle 3, basal, corona of long hooks, with hooks 1 and 1'. Metabasal, half-spiral of principal rows, internal face on the right, and band of small hooks, external face. Fig. 4: tentacle 1, basal, corona of long hooks, with hook 1 central (1C). Metabasal, band of small hooks, external face. Fig. 5: tentacle 2, basal, corona of long hooks, with central hook 1 (1C). Metabasal, half-spiral of principal rows, internal face. Bars - Fig. $1=0.5 \mathrm{~mm}$; Figs $2-5=0.125 \mathrm{~mm}$ 
Remarks: the two specimens studied accord with the description and drawings of Gymnorhynchus (Molicola) horridus (Goodsir, 1841) Dollfus, 1935 (= Molicola horridus), found parasitizing M. mola from several
Mediterranean regions, European, and African Atlantic coasts (Dollfus 1942). The observation of the basal armature, the corona of the long falciform hooks with rounded extremities, posterior to the unarmed basis under LM,
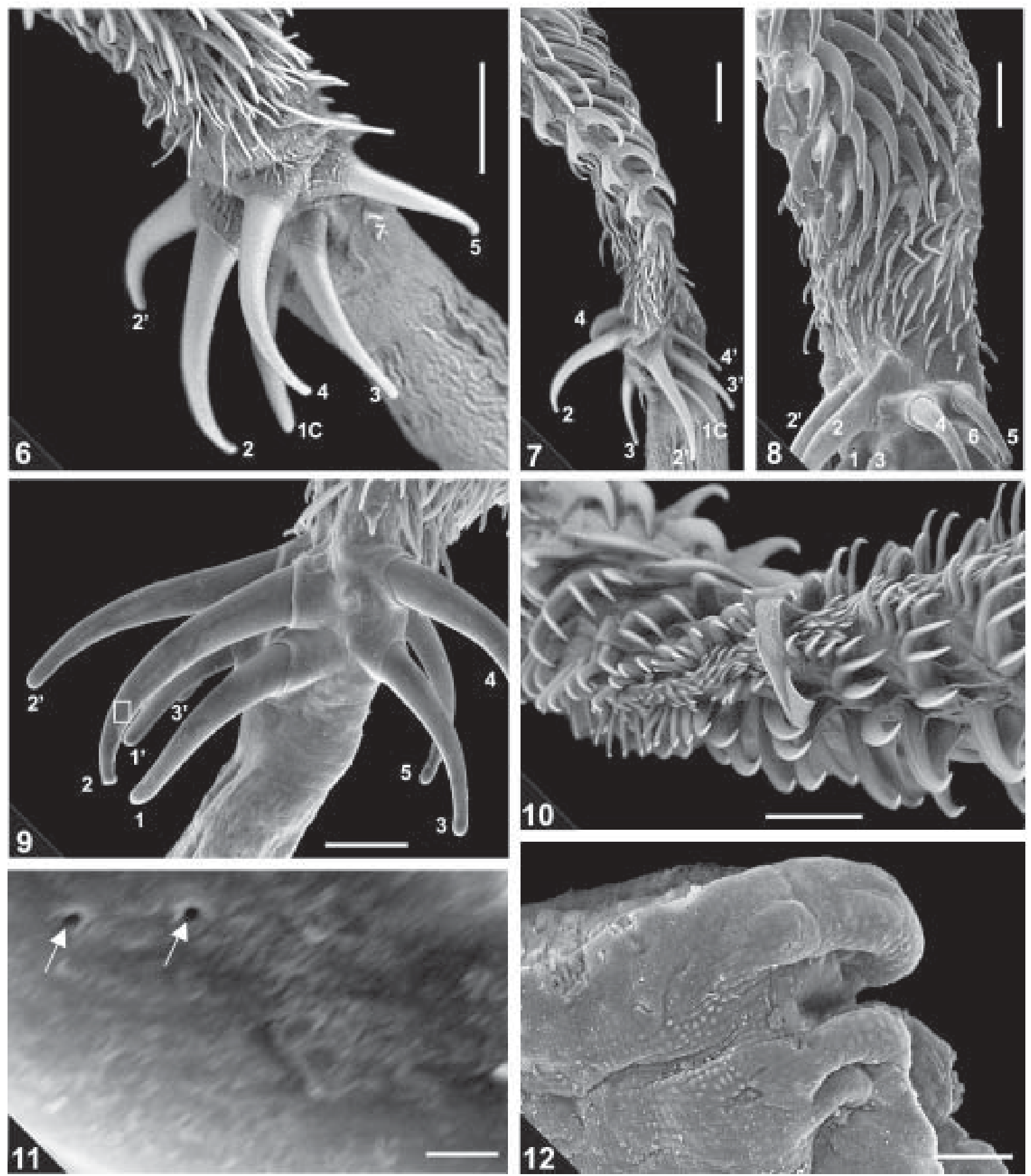

Molicola horridus, SEM* and Variable Pressure SEM. Fig. 6: tentacle 1, basal, corona of long hooks, with central hook 1(1C), antibothridial face. Fig. 7: tentacle 2, basal, corona of long hooks, with central hook 1(1C). Metabasal, half-spiral of principal rows, bothridial face. Fig. $8^{*}$ : tentacle 4, basal, corona of long hooks, with hooks 1 and 1', internal face upper portion. Metabasal, half-spiral of principal rows, internal face upper portion. Fig. 9*: tentacle 3, basal, corona of long hooks, with hooks 1 and 1', internal face on the left. Rectangle indicates the portion of Fig. 11. Fig. 10: metabasal, band of small hooks on the external face. Fig. 11*: detail of pores from one hook of the corona (arrows). Fig 12*: detail of papillae around the genital pore, latero-ventral view. Bars - Figs 6,7-10 = 80 $\mu \mathrm{m}$; Figs 8-9 = 50 $\mu$ m; Fig. $11=2 \mu \mathrm{m}$; Fig. $12=100 \mu \mathrm{mm}$ 
VPSEM, and SEM, permitted the establishment of the distribution pattern of these hooks around the tentacle. On the basis of the illustrations of this species after Dollfus (1942) only the basal corona of one of the tentacles can be observed, with hook one central, four long hooks and two smaller in a half-turn, what is equivalent to the pattern of the tentacles one and two observed in the Brazilian specimens. The description of these long basal hooks by Dollfus (1942) is general: “...vient ensuite une région portant de très longs crochets, beaucoup plus longs que ceux implantés antérieurement. Ces longs crochets, généralement au nombre de 9, ne sont pas tous de même longueur et sont accompagnés de quelques-uns (2 ou 3 ) beaucoup plus petits. Ces longs crochets ont une forme peu arquée et leur pointe n'est pas aiguë; ils s'insèrent sur les faces bothridiale et antibothridiale et sur le côté interne de la trompe (fig. 291); il n'y en a pas du côté externe (fig. 292)..."; at the bottom of the page the author comments about the difference in the number of these hooks after previous data.

Under VPSEM and SEM the pattern of distribution of the hooks in the basal corona, the presence of pores in these hooks and papillae around the genital pore are added to the original description.

The finding of the species in $P$. glauca represents a new host record and its first occurrence in Brazil.

\section{ACKNOWLEDGEMENTS}

To Dr Dely Noronha and Dr Luís Claudio Muniz-Pereira, Curators of the CHIOC, Rio de Janeiro, Brazil, Dr Jean-Lou Justine, Curator of Collection d'Helminthes, MNHN, Paris, France, for the loan of voucher specimens, Mr Bruno da Silva Vale, Dr Marcelo Pelajo Machado and Dr Henrique Leonel Lenzi for the assistance with the VPSEM from the Laboratorio de Patologia, IOC-Fiocruz, Prof. Jairo Pinheiro da Silva for the assistance with the SEM from the Instituto de Biofísica Carlos Chagas Filho, UFRJ, Mrs Heloisa Maria Nogueira Diniz, Mr Rodrigo Mexas, and Mr Bruno Eschinazi Vieira from the Laboratório de Produção e Processamento de Imagem Científica, IOC-Fiocruz, for figures processing, Dr Alberto Ferreira Amorim and Carlos Alberto Arfelli, from the Instituto de Pesca de Santos, São Paulo, for the identification of the fishes, the crew of the fishing boats Icanhema VI and Kiyomã from Santos for the help during the capture of the hosts.

\section{REFERENCES}

Alves DR, Luque JL 1999. Aspectos quantitativos das infrapopulações de metazoários parasitos de indivíduos jovens da corvina, Micropogonias furnieri (Osteichthyes: Sciaenidae) do litoral do Estado do Rio de Janeiro, Brasil. Contrib Avulsas sobre Hist Nat Brasil, Sér Zool 10: 1-4.

Alves DR, Luque JL 2000. Metazoários parasitos de indivíduos jovens da corvina, Micropogonias furnieri (Osteichthyes: Sciaenidae) do litoral do Estado do Rio de Janeiro, Brasil. Parasitol Dia 24: 40-45

Alves DR, Luque JL 2001a. Aspectos quantitativos das infrapopulações de metazoários parasitos de Micropogonias furnieri (Osteichthyes: Sciaenidae) do litoral do Estado do Rio de Janeiro, Brasil. Parasitol Dia 25: 30-35.

Alves DR, Luque JL 2001b. Community ecology of the metazoan parasites of white croaker, Micropogonias furnieri (Osteichthyes: Ophidiidae), from the coastal zone of the state of Rio de Janeiro, Brazil. Mem Inst Oswaldo Cruz 96:
145-153.

Amato JFR, Boeger WA, Amato SB 1991. Protocolos para Laboratório - Coleta e Processamento de Parasitos de Pescado, Imprensa Universitária, Universidade Federal Rural do Rio de Janeiro, Seropédica, 81 pp.

Bates RM 1990. A checklist of the Trypanorhyncha (Platyhelminthes: Cestoda) of the World (1935-1985). Natl Mus Wales, Zool Ser, 1: 1-218.

Brooks DR 1993. Extending the symbiotype concept to host voucher specimens. J Parasitol 79: 631-633.

Campbell RA, Beveridge I 1994. Order Trypanorhyncha Diesing, 1863. In LF Khalil, RA Bray, A Jones (eds), Keys to the Cestode Parasites of Vertebrates, Chapter 7, CAB International, Cambridge, $751 \mathrm{pp}$.

Carvajal J, Rego AA 1983. Progrillotia dollfusi sp. n. (Cestoda: Trypanorhyncha) parasito de pescada do litoral brasileiro. Mem Inst Oswaldo Cruz 78: 231-234.

Dollfus RP 1942. Études critiques sur les tetrarhynques du Muséum de Paris. Arch Mus Natl Hist Nat (Paris) 19: 1466.

Heinz M, Dailey MD 1974. The Trypanorhyncha (Cestoda) of elasmobranch fishes from Southern California and Northern Mexico. Proc Helm Soc Wash 41: 161-169.

Iwata S 1939. The classification list of Cestoidea in Japan. Vol Jub Prof Sadao Yoshida 2: 281-284.

Knoff M, São Clemente SC, Pinto RM, Gomes DC 2001a. Nematodes of elasmobranch fishes from the southern coast of Brazil. Mem Inst Oswaldo Cruz, 96: 81-87.

Knoff M, São Clemente SC, Pinto RM, DC Gomes 2001 b. Digenea and Acanthocephala of elasmobranch fishes from the southern coast of Brazil. Mem Inst Oswaldo Cruz 96: 1095-1101.

Palm HW 1997. Trypanorhynch cestodes of commercial fishes from northeast Brazilian coastal waters. Mem Inst Oswaldo Cruz 92: 69-79.

Pereira Jr J 1993. O complexo de espécies de Trypanorhyncha (Cestoda), em corvinas Micropogonias furnieri do Rio Grande do Sul. Arq Fac Vet UFRGS 21: 58-70.

Pereira Jr J 1998. Trypanorhyncha (Cercomeromorphae, Eucestoda) nos Scianidae (Neopterygii, Perciformes) do Litoral do Rio Grande do Sul: Sistemática, Estrutura das Comunidades Componentes e sua Utilização como Indicadores da Estrutura Trófica da Assembléia Hospedeira, PhD Thesis, Universidade Federal do Paraná, Curitiba, 243 pp.

Rego AA 1987. Redescrição de Pterobothrium crassicolle Diesing, 1850 (Cestoda: Trypanorhyncha) e revalidação da espécie. Mem Inst Oswaldo Cruz 82: 51-53.

Rego AA, Santos JC, Silva PP 1974. Estudos de cestóides de peixes do Brasil. Mem Inst Oswaldo Cruz 72: 187-204.

São Clemente SC 1986a. Plerocercos de Trypanorhyncha, parasitos de Micropogonias furnieri (Desmarest) no litoral do Rio de Janeiro. Atas Soc Biol RJ 26: 29-36

São Clemente SC 1986b. Prevalência e intensidade média de infecção de plerocercos de Trypanorhyncha, parasitando corvina Micropogonias furnieri (Desmarest) no litoral do Rio de Janeiro. Atas Soc Biol RJ 26: 37-44.

São Clemente SC 1987. Plerocercos de cestóides da ordem Trypanorhyncha, em corvina Micropogonias furnieri (Desmarest) e sua importância na inspeção sanitária do pescado. Arq Flu Med Vet 2: 82-83.

São Clemente SC, Coelho MRT, Serra Freire NM 1991. Cestóides parasitos de bagre Netuma barba (Lacépède, 1803) pescados no litoral do Rio de Janeiro e comercialzados para consumo humano. Arq Univ Fed Rur RJ 14: 27-34. 
São Clemente SC, Matos E, Uchoa CM, Matos P 1993. Trypanorhynch plerocerci in fish of commercial importance in Brazil. Parasitol Dia 7: 52-53.

São Clemente SC, Lima FC, Uchoa CM 1995. Parasitos de Balistes vetula (L.) e sua importância na inspeção do pescado. Rev Brasil Cienc Vet 2: 39-41.

São Clemente SC, Silva CM, Gottschalk S 1997. Prevalência e intensidade de infecção de cestóides Trypanorhyncha em anchovas, Pomatomus saltatrix (L.) do litoral do Rio de Janeiro, Brasil. Parasitol Dia 21: 54-57. 